\title{
RHEUMATIC COMPLAINTS IN AN URBAN POPULATION
}

BY

\author{
J. H. KELLGREN, J. S. LAWRENCE, and JEAN AITKEN-SWAN \\ From the Walkden Miners' Clinic and the Departments of Rheumatism Research \\ and Occupational Health, University of Manchester
}

(RECEIVED FOR PUBLICATION JANUARY 24, 1953)

During a recent study of rheumatic complaints among coal-miners, the incidence of similar complaints in the general population of a Lancashire town was investigated, and information was collected about occupational, climatic, and other possible factors which might be related to these complaints. Details of the method of survey and its completeness have already been discussed (Lawrence and AitkenSwan, 1952) so that the method of study need only be summarized here.

\section{Method}

The survey was carried out during 1949-50 in Leigh. This is an industrial town in South Lancashire which, according to the 1951 census, had a population of 48,714 . A random sample was taken of every tenth house and all individuals normally resident at that address and over the age of 15 years were interviewed by a specially trained medico-social worker. Each individual was asked whether he or she had suffered from rheumatism or from lumbago, sciatica, fibrositis, arthritis, neuritis, or any other aches or pains during the past 5 years, or before. Similar complaints present at the time of interview were also recorded. If a positive answer was given to any of these questions, information was collected about the site of pain, its duration, and any resulting loss of working time. Details of the individual's occupation and any unusual climatic exposure, past injury, or mechanical stress at work were also recorded, together with the type of dwelling. A list of houses officially classified as damp was also provided by the council inspector.

All individuals with rheumatic complaints were subsequently visited by a member of the medical staff of the University Rheumatism Centre. This physician checked the history and carried out a simple clinical examination designed to exclude complaints due to non-rheumatic diseases, and where possible to classify the rheumatic complaints under certain agreed diagnostic headings.

Unfortunately the diagnostic criteria for most rheumatic diseases are not clearly defined. The more advanced stages of diseases such as rheumatoid arthritis, ankylosing spondylitis, and osteo-arthritis can be recognized with some certainty, but the large variety of more transient painful syndromes which are usually called "fibrositis", "neuritis", or "lumbago" are less easily defined. Where the history and physical signs were definite enough for a diagnosis, such as rheumatoid or osteo-arthritis, to be made with reasonable confidence, this was recorded as the cause of pain, but where the diagnosis was uncertain the cause of pain was given as "undetermined", thus avoiding such vague terms as "lumbago" and "fibrositis".

During the past decade much attention has been given to disorders of the intervertebral disks, and it has become fashionable to attribute certain types of brachial, sciatic, and back pain to prolapse or degenerative changes in these disks. An attempt was therefore made to separate these conditions from the mass of painful disorders of undetermined nature. Only a few of those placed in this category were considered to have had a definite disk prolapse. The majority were of the type having a history of recurrent low back pain, often with some pain in the leg and with restriction of back movements, particularly the movement of extension in the lumbar region. The diagnosis of disk degeneration in such cases has been supported by a clinical and radiological study of workmen in the 5th decade (Kellgren and Lawrence, 1952), in which a significant association was found between these symptoms and signs and the radiological changes of disk degeneration as defined by Friberg and Hirsch (1949) and Schmorl and Junghanns (1951).

Many other diagnostic categories such as rheumatic fever, gout, osteochondritis, synovitis, bursitis, panniculitis, etc., were included and where the pain was considered to be entirely psychogenic it was recorded as such: On the other hand, most shoulder and "thoracic outlet" syndromes were classed as undetermined shoulder or brachial pains, because of the difficulties of diagnosis.

As those without complaint of pain were not examined, no information on asymptomatic forms of arthritis was obtained. This survey therefore deals exclusively with rheumatic complaints.

In all, 1,393 houses were selected for study and 3,515 individuals were questioned by a social worker; this part of the survey was 98 per cent. complete. Of the 1,407 individuals with rheumatic complaints, all but 98 were seen by a physician; thus the diagnostic part of the survey is only 93 per cent. complete, but the information available from the questionnaire for the 7 per cent. of defaulters does not suggest that their inclusion would have altered the results materially. 
TABLE I

RHEUMATIC COMPLAINTS BY DIAGNOSIS "IN PAST 5 YEARS" AND "NOW"

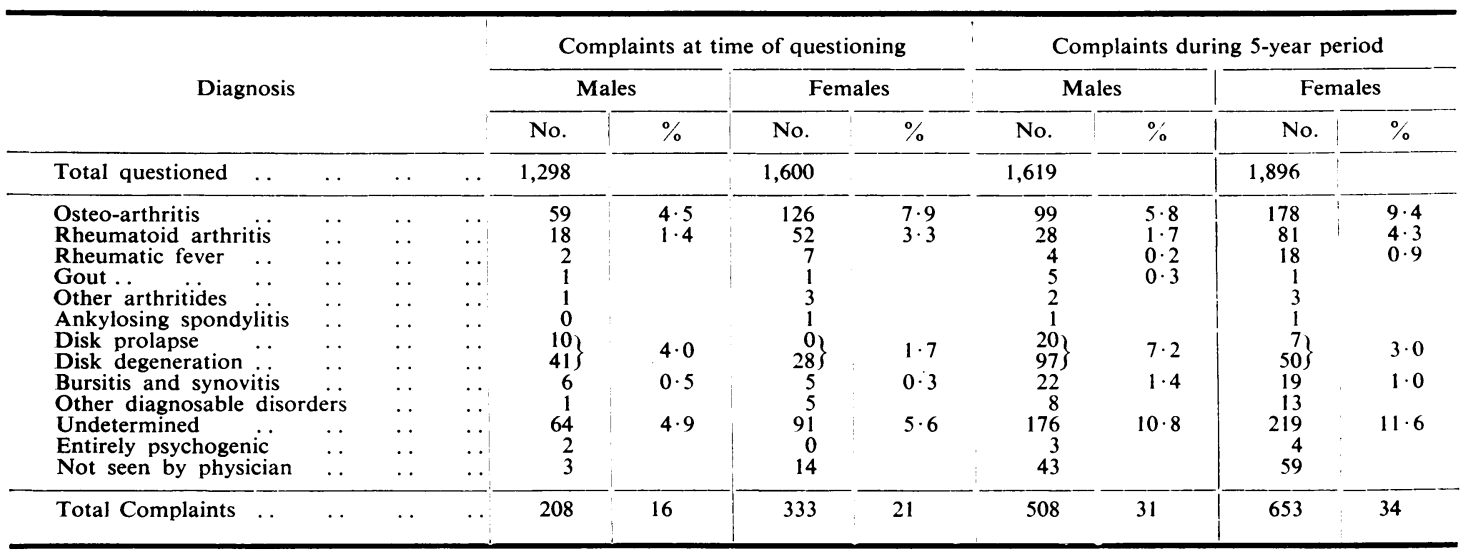

\section{Results}

Incidence of Complaints.-Many rheumatic complaints are episodic, and for this reason the complaint rate during the past 5 years was considered to give the most useful information. When complaints prior to the past 5 years were included, the overall complaint rate only rose from 33 per cent. to 40 per cent. This was expected, since only severe disabling complaints are likely to be remembered for long

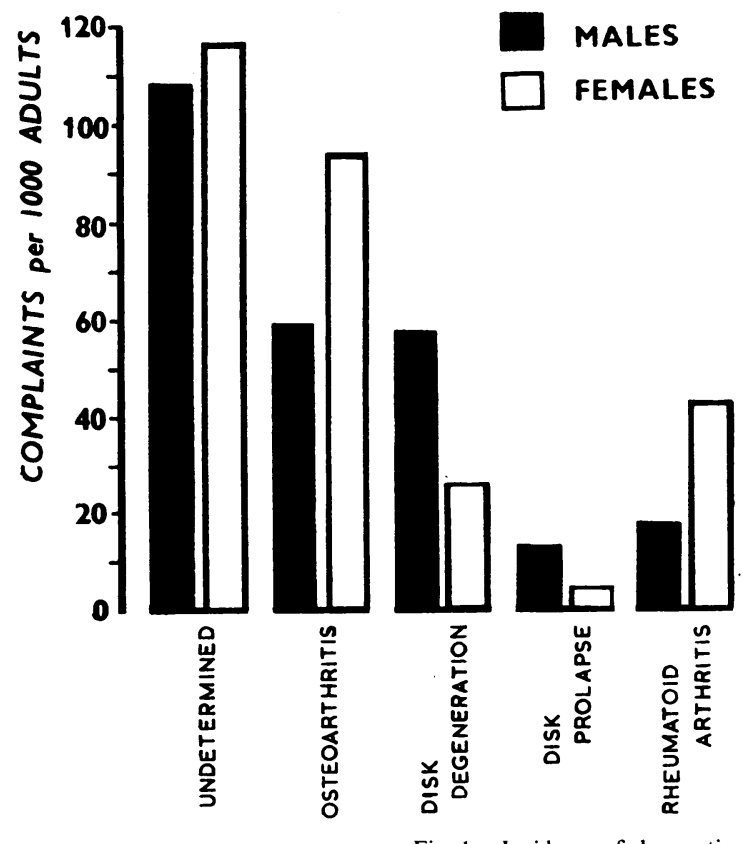

periods. The incidence of complaints present at the time of questioning eliminates errors due to memory, but does not give a satisfactory assessment of episodic complaints. Furthermore, this question was only introduced after the first few houses had been studied, so that our figures for "rheumatism now" are not quite complete. The overall complaint rate of "rheumatism now" was, however, 19 per cent., being considerably less than that for the 5-year period.

Incidence by Diagnosis.-Table I shows a detailed comparison of the incidence of complaints during the past 5 years and those present at the time of questioning classified by diagnoses. Fig. 1 illustrates the incidence of the various diagnostic categories per 1,000 of the population studied. It will be seen from Table I that the incidence of complaints due to osteo-arthritis and rheumatoid arthritis is not greatly increased by taking the 5 -year period, while all the other diagnostic groups show a considerably increased incidence in the 5-year period. This is well illustrated by gout, which is a notoriously episodic complaint. The incidence in males based on complaints at the time of questioning is only about 1 per

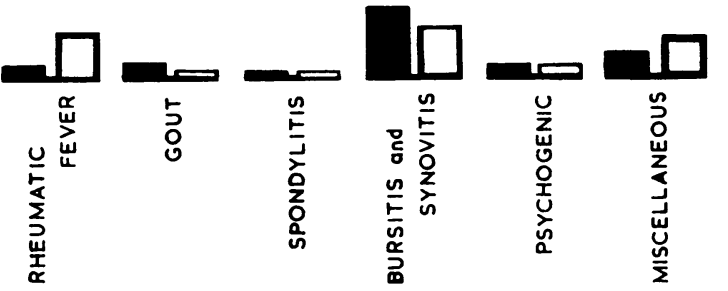


1,000 , but when we include the 5 -year period the incidence rises to about 3.5 per thousand. Ankylosing spondylitis in its fully developed form is also an uncommon disease with an incidence of less than 1 per thousand. Most forms of infective arthritis and rare arthritic syndromes have been classed together under "other arthritides", but even so their incidence is very low. Tuberculosis of bones and joints and osteomyelitis were, however, excluded from the survey as non-rheumatic. The disk disorders were separated into disk prolapse with nerve-root involvement and disk degeneration in which the symptoms were considered to be due to mechanical factors arising from disruption of the disk, particularly its annulus fibrosus. As expected, disk prolapse occurred mainly in the younger age groups. Since both syndromes are presumably the result of a similar underlying pathological process they have been classed together under the heading of disk disorders in all subsequent tables.

Under the heading of other diagnosable disorders we placed conditions such as osteochondritis, Paget's disease, panniculitis, fat hernia, and a variety of other more or less defined diseases, but they are clearly not an important cause of pain.

A surprising finding was the small number in whom psychogenic pain could be diagnosed with confidence. In this respect our findings in this field differed from our experience in hospital practice where the patient with " psychogenic rheumatism " is a familiar figure. Such patients are, however, chronic haunters of hospital clinics and are usually seen by so many specialists that an exaggerated impression of their frequency is obtained from hospital work. It was, however, recognized that many individuals with complaints may have suffered from some degree of mental or emotional ill-health, since such disorders are very common, but it was not easy to assess the part this played in the production of their symptoms.
The true incidence of rheumatic fever cannot be obtained from the figures in this survey, since only those individuals with articular symptoms would be picked up by the method of questioning. Although a history of preceding infection and cardiac involvement was considered as definite evidence of rheumatic fever, this was not present in all instances, some individuals merely giving a history of an acute polyarthritis which had been labelled as rheumatic fever at the time of the illness. On the other hand the diagnoses of osteo-arthritis and rheumatoid arthritis were considered to be fairly reliable and comprehensive, but it should be realized that all grades of these diseases were included, so that our figures do not represent the incidence of severe crippling disease which was only present in a small proportion.

From Fig. 1 it is clear that the majority of rheumatic complaints can be classified under the main headings of osteo-arthritis, rheumatoid arthritis, disk disorders, and pains of undetermined nature. In further considering our material, we confined ourselves to these four headings plus a fifth group which contains all the remaining diagnostic categories classed together under the one heading of "other miscellaneous diagnosable rheumatic complaints".

Incidence by Age.- Table II shows the incidence of complaints in three main age groups (under 29, $30-49$, and over 50 years) under the main diagnostic headings, and the proportional incidence of these complaints by decades is illustrated in Fig. 2 (overleaf).

The incidence of osteo-arthritis increases rapidly with advancing age and reaches 15 per cent. in males and 25 per cent. in females, over 60 years of age. The high incidence of osteo-arthritis in females has been noted previously (Newman, 1924) and will be discussed later.

Rheumatoid arthritis has its highest incidence in

TABLE II

RHEUMATIC COMPLAINTS IN A 5-YEAR PERIOD BY SEX AND AGE GROUP

\begin{tabular}{|c|c|c|c|c|c|c|c|c|c|c|c|c|}
\hline \multirow[t]{2}{*}{ Sex } & \multirow[t]{2}{*}{$\begin{array}{c}\text { Age Group } \\
\text { (years) }\end{array}$} & \multirow[t]{2}{*}{ Total } & \multicolumn{2}{|c|}{ Osteo-Arthritis } & \multicolumn{2}{|c|}{$\begin{array}{l}\text { Rheumatoid } \\
\text { Arthritis }\end{array}$} & \multicolumn{2}{|c|}{ Disks } & \multicolumn{2}{|c|}{ Undetermined } & \multicolumn{2}{|c|}{ Miscellaneous } \\
\hline & & & No. & $\%$ & No. & $\%$ & No. & $\%$ & No. & $\%$ & No. & $\%$ \\
\hline \multirow[t]{2}{*}{ Male } & $\begin{array}{l}15-29 \\
30-49 \\
50 \div\end{array}$ & $\begin{array}{l}416 \\
660 \\
543\end{array}$ & $\begin{array}{r}1 \\
18 \\
80\end{array}$ & $\begin{array}{l}0 \cdot 2 \\
3 \\
15\end{array}$ & $\begin{array}{r}2 \\
8 \\
18\end{array}$ & $\begin{array}{l}0 \cdot 5 \\
1 \\
3\end{array}$ & $\begin{array}{r}7 \\
63 \\
47\end{array}$ & $\begin{array}{r}2 \\
10 \\
9\end{array}$ & $\begin{array}{r}18 \\
113 \\
45\end{array}$ & $\begin{array}{r}4 \\
17 \\
8\end{array}$ & $\begin{array}{r}8 \\
20 \\
17\end{array}$ & $\begin{array}{l}2 \\
3 \\
3\end{array}$ \\
\hline & Total & 1,619 & 99 & & 28 & & 117 & & 176 & & 45 & \\
\hline \multirow[t]{2}{*}{ Female } & $\begin{array}{l}15-29 \\
30-49 \\
50+\end{array}$ & $\begin{array}{l}500 \\
712 \\
684\end{array}$ & $\begin{array}{r}1 \\
30 \\
147\end{array}$ & $\begin{array}{c}0 \cdot 2 \\
4 \\
22\end{array}$ & $\begin{array}{r}8 \\
23 \\
50\end{array}$ & $\begin{array}{l}2 \\
3 \\
7\end{array}$ & $\begin{array}{r}1 \\
20 \\
36\end{array}$ & $\begin{array}{l}0 \cdot 2 \\
3 \\
5\end{array}$ & $\begin{array}{r}44 \\
123 \\
52\end{array}$ & $\begin{array}{r}9 \\
17 \\
8\end{array}$ & $\begin{array}{l}13 \\
27 \\
19\end{array}$ & $\begin{array}{l}3 \\
4 \\
3\end{array}$ \\
\hline & Total & 1,896 & 178 & & 81 & & 57 & & 219 & & 59 & \\
\hline
\end{tabular}




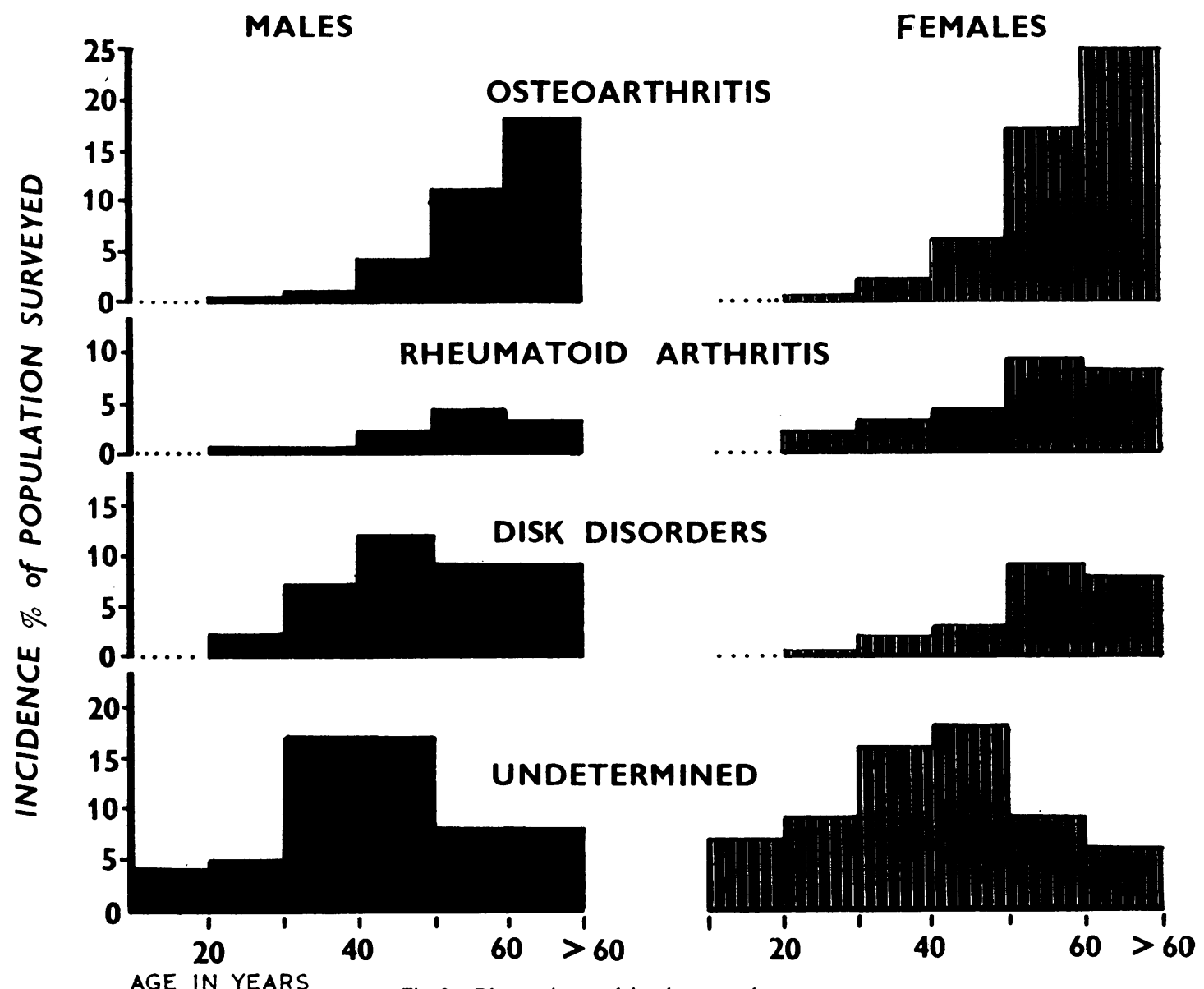

Fig. 2.-Rheumatic complaints by age and sex.

the 6th decade where it rises to a maximum of 4 per cent. in males and 9 per cent. in females. The usual female preponderance is shown. Both rheumatoid arthritis and osteo-arthritis are often thought of as severe crippling diseases, but there are many individuals suffering from minor degrees of the rheumatoid or osteo-arthritic processes which can be readily recognized clinically but which give rise to only minor complaints. Thus it must be remembered that only a proportion of those affected are seriously disabled.

Disk disorders most commonly give rise to complaints in middle adult life; thus the maximum incidence in males (12 per cent.) is found in the 5 th decade, and there is already an incidence of 7 per cent. in the 4th decade at a time when the incidence of rheumatoid and osteo-arthritis is negligible. The incidence in males was more than twice that in females, in whom disk disorders tended to occur at a later age.
Rheumatic complaints of undetermined nature were found at an early age, there being an appreciable incidence in both the 2nd and 3rd decades and a maximal incidence of about 17 per cent. in the 4th and 5th decades, after which the incidence drops to about 7 per cent., both sexes being about equally affected throughout. The falling incidence of pain of undetermined nature in the higher age groups where the incidence of osteo-arthritis and rheumatoid arthritis is rising, suggests that at least some proportion of these more trivial painful conditions may represent early and as yet undiagnosable manifestations of these more serious diseases. But there are clearly many obscure complaints with a greater or lesser psychogenic component which form the hard core of the pains of undetermined nature, and the high incidence in the 4th and 5th decade might possibly be related to increased responsibility at this time of life and a host of other factors about which we do not propose to speculate. 
TABLE III

LOSS OF WORKING TIME THROUGH RHEUMATISM IN A 5-YEAR PERIOD BY SEX

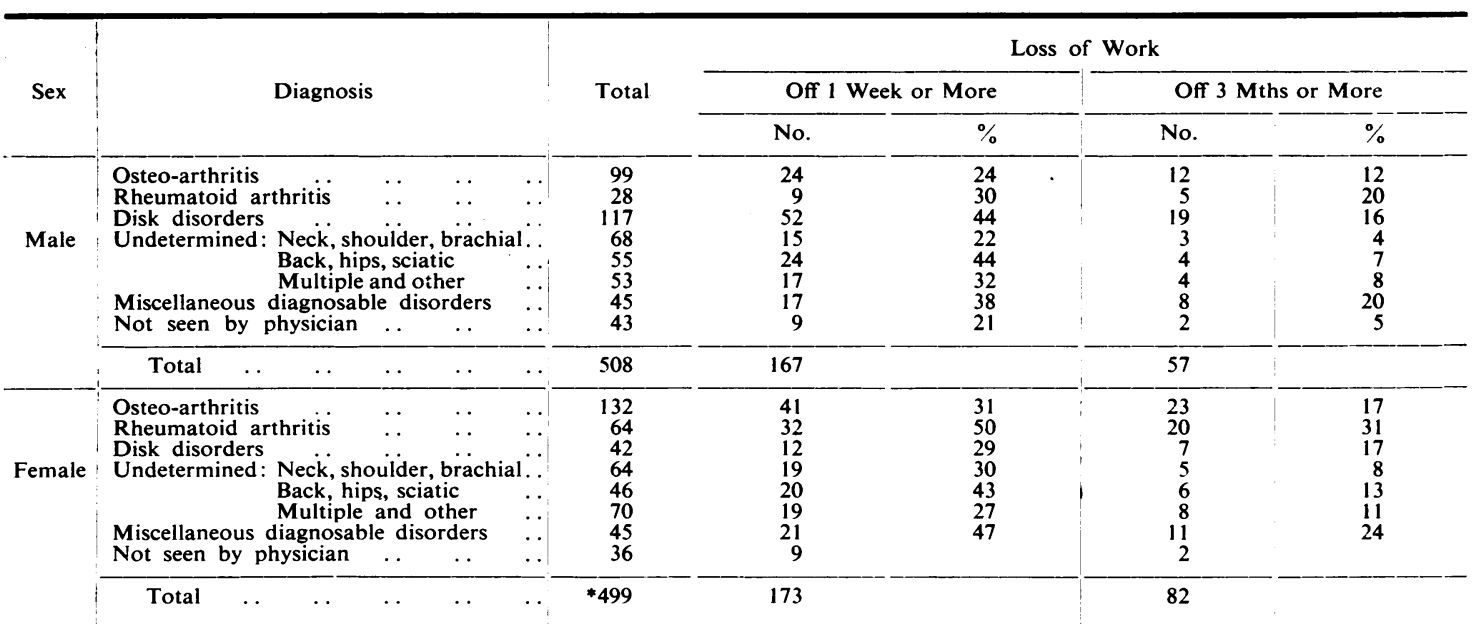

* The total number of females is only 499 since it was not possible to assess loss of working time in 154 housewives with rheumatic complaints who did not go out to work.

Loss of Working Time.-This was analysed by sex and diagnosis, excluding the 154 whole-time housewives in whom this assessment proved impracticable. The main findings are shown in Table III, which makes it clear that even rheumatoid arthritis, which is the most disabling form of rheumatism, is not always a severe crippling disease. Indeed, half the individuals with this condition had lost no working time during the past 5 years. Nevertheless, 20 per cent. of males and 31 per cent. of females suffering from this disease had lost more than 3 months of working time. The proportionate loss of working time is next highest in the miscellaneous group, which is followed by disk disorders and osteoarthritis, complaints of undetermined nature being the least disabling.

In assessing loss of working time in the total population, one must consider the total numbers affected by the various rheumatic diseases, and if this is done it is clear that amongst males most loss of working time results from disk disorders, undetermined pains, and osteo-arthritis in that order, while amongst females osteo-arthritis causes most loss of working time, though it is followed closely by rheumatoid arthritis and complaints of undetermined nature.

Medical Care.-Shortly after the start of the survey a question was introduced to find out the extent to which people with rheumatic complaints obtained medical care. The results are seen in Table IV (overleaf), which shows the numbers in each diag- nostic group who had consulted a general practitioner, together with the number of those who had, in addition, been referred to hospital, either as outpatients or in-patients. In this Table the 154 wholetime housewives have been included. It will be seen that the consultation rate with complaints of undetermined nature is only about 50 per cent. This is not surprising, since many of these conditions are quite trivial and of short duration. On the other hand only five out of 26 (19 per cent.) men with rheumatoid arthritis had failed to consult a doctor, and a similar high consultation rate was noted in males with disk disorders. But thirty females with rheumatoid arthritis (38 per cent.), failed to consult a doctor, and the proportion rises to 50 per cent. amongst females with osteoarthritis.

Although in some cases failure of consultation is due to the relatively trivial nature of the symptoms and disability, there is no doubt that much of it is due to a general belief that "rheumatism is incurable" and that the doctor can do nothing about it. These figures also suggest that estimates of the incidence of these conditions based upon medical practitioners' certificates are likely to be much too low.

A study of the figures for attendance at hospital is even less encouraging. Thus the numbers referred to hospital correspond roughly with those losing 3 months or more of working time while only about one quarter of patients with this degree of disability obtain in-patient treatment. 
TABIF IV

CONSULTATION RATES IN PERSONS COMPLAINING OF RHEUMATISM IN A 5-YEAR PERIOD, BY SEX

\begin{tabular}{|c|c|c|c|c|c|c|c|c|c|c|}
\hline \multirow{3}{*}{ Sex } & & & \multirow{3}{*}{$\begin{array}{c}\text { Total } \\
\text { Asked }\end{array}$} & \multirow{3}{*}{$\begin{array}{l}\text { Not } \\
\text { Asked }\end{array}$} & \multirow{2}{*}{\multicolumn{2}{|c|}{$\begin{array}{l}\text { Consulted at } \\
\text { Doctor }\end{array}$}} & \multicolumn{4}{|c|}{ Referred to Hospital } \\
\hline & \multirow{2}{*}{\multicolumn{2}{|c|}{ Diagnosis }} & & & & & \multicolumn{2}{|c|}{ Out-patient } & \multicolumn{2}{|c|}{ In-patient } \\
\hline & & & & & No. & $\begin{array}{l}\text { Per cent. } \\
\text { of those } \\
\text { asked }\end{array}$ & No. & $\begin{array}{l}\text { Percent. } \\
\text { of those } \\
\text { asked }\end{array}$ & No. & $\begin{array}{c}\text { Percent. } \\
\text { of those } \\
\text { asked }\end{array}$ \\
\hline \multirow{9}{*}{ Male } & Osteo-arthritis & . & 86 & 13 & 53 & 62 & 8 & 9 & 4 & 5 \\
\hline & Rheumatoid arthritis & $\cdots$ & 26 & 2 & 21 & 81 & 5 & 19 & 1 & 4 \\
\hline & Disk disorders ... & $\ldots$ & 106 & $1 \overline{1}$ & 86 & 81 & 19 & 18 & 4 & 4 \\
\hline & Undetermined: Neck, shoulder, brachial & $\cdots$ & 60 & & 26 & 43 & 3 & 5 & 1 & 2 \\
\hline & Back, hips, sciatic .. & $\cdots$ & 48 & 20 & 29 & 60 & 4 & 8 & 1 & 2 \\
\hline & Multiple and other .. & $\ldots$ & 48 & & 24 & 50 & 3 & 6 & 3 & 6 \\
\hline & Miscellaneous diagnosable disorders .. & $\cdots$ & 41 & 4 & 25 & 61 & 3 & 7 & $i$ & 2 \\
\hline & Not seen by physician .. & . & 33 & 10 & 24 & 73 & 2 & 6 & $i$ & 3 \\
\hline & Total & . & 448 & 60 & 288 & & 47 & & 16 & \\
\hline \multirow{9}{*}{ Females } & Osteo-arthritis & . & 166 & 12 & 83 & 50 & 23 & 14 & 5 & 3 \\
\hline & Rheumatoid arthritis & $\cdots$ & 79 & 2 & 49 & 62 & 16 & 20 & 6 & 8 \\
\hline & Disk disorders & $\ldots$ & 53 & 4 & 22 & 42 & 11 & 21 & 1 & 2 \\
\hline & Undetermined: Neck, shoulder, brachial & $\cdots$ & 74 & & 34 & 46 & 6 & 8 & () & 0 \\
\hline & Back, hips, sciatic .. & $\ldots$ & 57 & 12 & 34 & 60 & 9 & 16 & 1 & 2 \\
\hline & Multiple and other & $\therefore$ & 761 & & 34 & 45 & 11 & 14 & () & 0 \\
\hline & Miscellaneous diagnosable disorders & $\cdots$ & 54 & 5 & 26 & 48 & 11 & 20 & 4 & 7 \\
\hline & Not seen by physician .. $\quad$. & . & 46 & 13 & 22 & 46 & 5 & 11 & $i$ & 2 \\
\hline & Total .. & . & 605 & 48 & 304 & & 102 & & 18 & \\
\hline
\end{tabular}

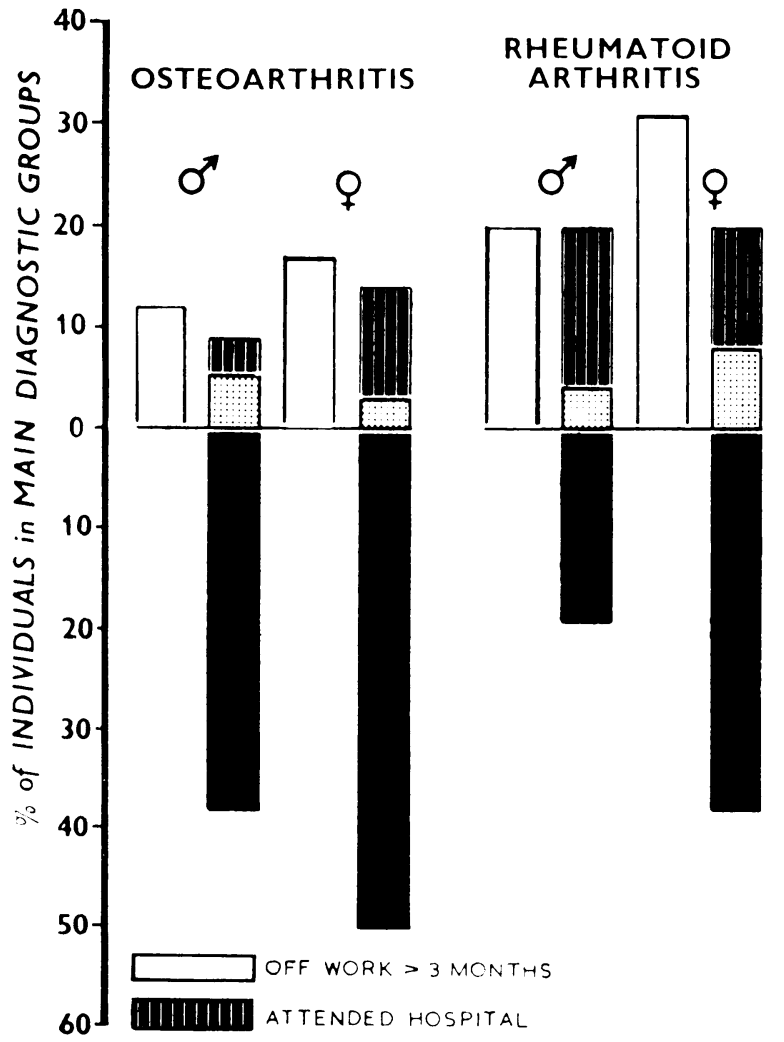

DISK DISORDERS UNDETERMINED

(1)

ATTENDED HOSPITAL

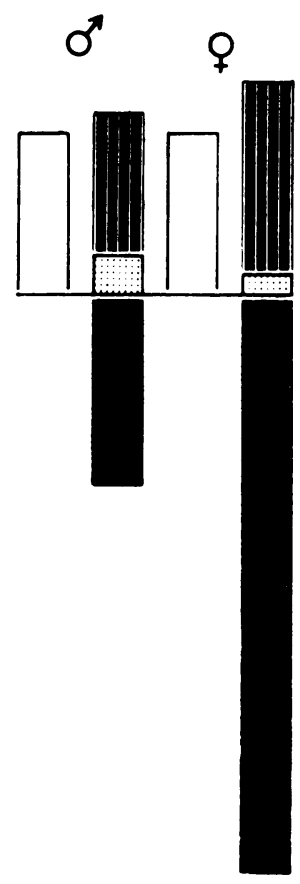

○

要

Fig. 3.--Degree of disability and hospital treatment compared. 
TABLE V

RHEUMATIC COMPLAINTS AND PREDOMINANT WORK, BY SEX

\begin{tabular}{|c|c|c|c|c|c|c|c|c|c|c|c|c|c|}
\hline \multirow{2}{*}{ Sex } & \multirow{2}{*}{\multicolumn{4}{|c|}{$\begin{array}{l}\text { Predominant } \\
\text { Work }\end{array}$}} & \multirow{2}{*}{$\begin{array}{c}\text { Total } \\
\text { Workers }\end{array}$} & \multicolumn{2}{|c|}{ Osteo-arthritis } & \multicolumn{2}{|c|}{ Rheumatoid Arthritis } & \multicolumn{2}{|c|}{ Disk Disorders } & \multicolumn{2}{|c|}{ Undetermined } \\
\hline & & & & & & $\begin{array}{c}\text { Actual } \\
\text { No. }\end{array}$ & $\begin{array}{l}\text { Expected } \\
\text { No.* }\end{array}$ & $\begin{array}{c}\text { Actual } \\
\text { No. }\end{array}$ & $\begin{array}{l}\text { Expected } \\
\text { No. }\end{array}$ & $\begin{array}{c}\text { Actual } \\
\text { No. }\end{array}$ & $\begin{array}{l}\text { Expected } \\
\text { No. }\end{array}$ & $\begin{array}{c}\text { Actual } \\
\text { No. }\end{array}$ & $\begin{array}{l}\text { Expected } \\
\text { No. }\end{array}$ \\
\hline \multirow[t]{2}{*}{ Male } & $\begin{array}{l}\text { Mining } \\
\text { Factories } \\
\text { Outdoor } \\
\text { Mills } \\
\text { Tradesmen } \\
\text { Business an } \\
\text { Other }\end{array}$ & $\begin{array}{l}\ldots \\
\cdots \\
\cdots \\
\text { nd } \mathrm{Pr} \\
\ldots\end{array}$ & $\begin{array}{l}\ldots \\
\ldots \\
\ldots \\
\cdots \\
\text { fession } \\
\ldots\end{array}$ & $\begin{array}{l}\ldots \\
\ldots \\
\ldots \\
\therefore \\
\ldots\end{array}$ & $\begin{array}{l}539 \\
265 \\
239 \\
168 \\
152 \\
131 \\
125\end{array}$ & $\begin{array}{r}49 \\
9 \\
15 \\
8 \\
2 \\
7 \\
9\end{array}$ & $\begin{array}{r}41 \\
14 \\
14 \\
10 \\
10 \\
8 \\
5\end{array}$ & $\begin{array}{l}6 \\
6 \\
2 \\
2 \\
6 \\
4 \\
2\end{array}$ & $\begin{array}{r}10 \\
4 \\
4 \\
3 \\
3 \\
2 \\
1\end{array}$ & $\begin{array}{r}57 \\
11 \\
14 \\
14 \\
11 \\
6 \\
4\end{array}$ & $\begin{array}{r}45 \\
18 \\
19 \\
13 \\
12 \\
9 \\
7\end{array}$ & $\begin{array}{r}53 \\
29 \\
35 \\
16 \\
16 \\
18 \\
9\end{array}$ & $\begin{array}{l}60 \\
26 \\
28 \\
19 \\
16 \\
13 \\
11\end{array}$ \\
\hline & Total & $\ldots$ & $\ldots$ & $\ldots$ & 1,619 & 99 & & 28 & & 117 & & 176 & \\
\hline \multirow[t]{2}{*}{ Female } & $\begin{array}{l}\text { Domestic } \\
\text { Mills } \\
\text { Factories } \\
\text { Business an } \\
\text { Trade } \\
\text { Other }\end{array}$ & $\begin{array}{l}\ldots \\
\ddot{n d} \mathbf{P} \\
\ldots \\
\ldots\end{array}$ & $\begin{array}{l}\cdots \\
\cdots \\
\text { fession } \\
\ldots \\
\ldots\end{array}$ & $\begin{array}{l}\cdots \\
\cdots \\
a \\
\cdots \\
\cdots\end{array}$ & $\begin{array}{r}880 \\
532 \\
156 \\
151 \\
112 \\
65\end{array}$ & $\begin{array}{r}117 \\
39 \\
5 \\
5 \\
9 \\
3\end{array}$ & $\begin{array}{r}122 \\
35 \\
6 \\
5 \\
8 \\
3\end{array}$ & $\begin{array}{r}45 \\
18 \\
4 \\
6 \\
5 \\
3\end{array}$ & $\begin{array}{r}46 \\
19 \\
5 \\
4 \\
4 \\
2\end{array}$ & $\begin{array}{r}40 \\
13 \\
1 \\
1 \\
0 \\
2\end{array}$ & $\begin{array}{r}35 \\
13 \\
3 \\
2 \\
3 \\
1\end{array}$ & $\begin{array}{r}90 \\
76 \\
16 \\
19 \\
12 \\
6\end{array}$ & $\begin{array}{r}100 \\
67 \\
18 \\
17 \\
12 \\
7\end{array}$ \\
\hline & Total & $\cdots$ & $\cdots$ & $\cdots$ & 1,896 & 178 & & 81 & & 57 & & 219 & \\
\hline
\end{tabular}

* "Expected" numbers based on rates for all males or all females in the three age groups shown in Table II.

Fig. 3 shows that patients with equivalent disability from disk disorders and pains of undetermined nature are more frequently referred to hospital than females with rheumatoid arthritis, or than both males and females with osteo-arthritis. These differences probably reflect the clinical interests of the local physicians and surgeons as well as a belief in the greater efficacy of hospital treatment in the disk and undetermined groups.

Occupation.- The incidence of the main rheumatic disorders in occupational groups is shown in Table V. The individual's predominant occupation, rather than his or her occupation at the time of survey, was chosen for this purpose.

Direct comparison between occupational groups would have been misleading because of the widely differing age composition of these groups. Thus among coal-miners there is a greater proportion of men over 50 years of age and fewer men under 30 than in other occupations. Among the females, the domestic workers, of whom 808 were housewives, were mostly over 50 years of age, while those employed in factories and trades were mostly under 30 years. We have, therefore, split each occupational group into three age groups-under 30 years, 30-49, and 50 and over. Taking the incidence of each rheumatic disorder for these age groups in our whole population from Table II we have calculated the expected number of individuals with osteo-arthritis, rheumatoid arthritis, etc., in each occupational group, and by comparing this expected number with the actual number one may see whether there appears to be any association between occupation and the four main rheumatic disorders.
It will be seen from the Table that amongst the women the actual incidence follows the expected incidence very closely indeed through most of the occupational and diagnostic groupings, but among the domestic workers there are rather more complaints due to disk disorders and among the mill workers rather more pains of undetermined nature. The men, however, show greater differences. Thus the coal-miners have more than the expected number of complaints due to osteo-arthritis and disk disorders, while nearly all the other occupations have the expected number or rather less. Amongst tradesmen the low incidence of osteo-arthritis is statistically significant $(P<0.05)$. The incidence of rheumatoid arthritis appears to be rather less amongst miners and other heavy workers and rather more amongst tradesmen and the business and professional groups, but this probably reflects the wellknown drift of the rheumatoid patient from heavy to light work. The undetermined pains are perhaps slightly in excess amongst the outdoor workers. On the whole the differences between the occupation groups are remarkably small, the only real difference being the low incidence of osteo-arthritis in male tradesmen and the high incidence of osteo-arthritis and disk disorders amongst miners. Although the numerical differences for the miners are not statistically significant, it must be remembered that in this Table we are comparing miners with a total population of which approximately one-third are miners. If we compare miners with non-miners, as was done in a previous study, significant differences are found (Lawrence and Aitken-Swan, 1952; Kellgren and Lawrence, 1952). 
TABLE VI

RHEUMATIC COMPLAINTS IN 5-YEAR PERIOD AND RELATED INJURIES

\begin{tabular}{|c|c|c|c|c|c|c|}
\hline \multirow{3}{*}{ Diagnosis } & \multicolumn{3}{|c|}{ Males } & \multicolumn{3}{|c|}{ Females } \\
\hline & \multirow[t]{2}{*}{$\begin{array}{c}\text { Total } \\
\text { Asked }\end{array}$} & \multicolumn{2}{|c|}{$\begin{array}{l}\text { Related } \\
\text { Injury }\end{array}$} & \multirow[t]{2}{*}{$\begin{array}{c}\text { Total } \\
\text { Asked }\end{array}$} & \multicolumn{2}{|c|}{$\begin{array}{c}\text { Related } \\
\text { Injury }\end{array}$} \\
\hline & & No. & $\%$ & & No. & $\%$ \\
\hline $\begin{array}{l}\text { Osteo-arthritis } \\
\text { Rheumatoid arthritis } \\
\text { Disk disorders } \\
\text { Other rheumatic disorders } \\
\text { Undetermined }\end{array}$ & $\begin{array}{r}94 \\
26 \\
112 \\
45 \\
171\end{array}$ & $\begin{array}{r}32 \\
1 \\
13 \\
4 \\
9\end{array}$ & $\begin{array}{r}34 \\
4 \\
12 \\
9 \\
5\end{array}$ & $\begin{array}{r}176 \\
79 \\
57 \\
59 \\
213\end{array}$ & $\begin{array}{r}30 \\
4 \\
9 \\
2 \\
14\end{array}$ & $\begin{array}{r}517 \\
5 \\
20 \\
3 \\
7\end{array}$ \\
\hline Total .. & 448 & 59 & 13 & 584 & 59 & 10 \\
\hline
\end{tabular}

Injury.-In Table VI we have set out the number of individuals in each of the main diagnostic groups who gave a history of previous injury related to their complaint. If we assume that all individuals of the same sex with complaints form a homogeneous population in respect of injury, there is in males a highly significant association between osteo-arthritis and a history of previous injury $(P<0.001)$. In females there is a similar association, but it is less significant $(P<0 \cdot 01)$. These findings are in keeping with general clinical experience.

Special mechanical stresses at work were considered to represent sub-clinical injury and the number of individuals with such stress in the various diagnostic groups was considered. Again there appeared to be some association between mechanical stresses and osteo-arthritis in the males, but the differences were not statistically significant $(P<0 \cdot 1)$.

Climate.-The number of houses certified as damp by the council inspector was very small, so that figures for individuals living in these houses are too low for detailed analysis, but the findings shown in Table VII suggest that damp housing defined in this way does not greatly affect the incidence of rheumatic complaints. On the other hand, a substantial number of men stated that their working conditions were unusually cold or wet, and there does appear to be some association between such a $\sigma$ statement and complaints as a whole, and especially those due to disk disorders. Thus, if we consider all $\overrightarrow{\vec{B}}$ the 60 men working in the cold to be homogeneous in respect of rheumatic complaints, we should $\frac{}{5}$ expect to find four with complaints due to disk $\frac{\bar{\sigma}}{\bar{\omega}}$ disorder, but the actual figure is ten, this difference $\frac{\vec{\phi}}{\vec{\alpha}}$ being significant $(P<0 \cdot 01)$. If we similarly consider $\cong$ the 410 men working in the wet, we should expect $\%$ to find 31 with complaints due to disk disorders, but $\overrightarrow{0}$ the actual figure is 57 , a highly significant increase $\overrightarrow{-}$ $(P<0.001)$. The number of females claiming special $\vec{\omega}$ climatic exposure is small, but of the 63 women working in the wet, fifteen had complaints due to osteo-arthritis against an expected six. This differ- $\vec{N}$ ence is again significant $(P<0 \cdot 001)$.

These findings must be interpreted with great ir caution, since we only have data about complaints and not about anatomical changes in the joints and $\vec{A}$ disks. It seems unlikely that anatomical changes would be affected by climate, but it has been shown $\bar{O}$ that hyperalgesic deep tissues cause excessive pain when cooled (Kellgren and McGowan, 1948), and $\mathscr{E}$ such deep cooling will occur more easily in a wet than $\omega$ in a dry atmosphere. The anatomical changes of osteo-arthritis and disk degeneration are not always painful, though they are associated with painful episodes, and it may be that exposure to cold and damp increases susceptibility to these painful inci- $\stackrel{\mathbb{Q}}{\varrho}$ dents, thus increasing the complaint rate. Our $\overrightarrow{\overrightarrow{0}}$ clinical experience also suggests that individuals with disk disorders or generalized osteo-arthritis are particularly weather-sensitive, that is to say, their pain is aggravated by cold and damp. These individuals are thus more aware of cold and wet than the average individual, and would be more likely to claim that their working conditions were unusually cold and wet, thus producing the association noted above.

TABle VII

CLIMATIC EXPOSURE AND RHEUMATIC COMPLAINTS, BY SEX

\begin{tabular}{|c|c|c|c|c|c|c|c|c|c|c|c|c|c|c|c|c|}
\hline \multirow{4}{*}{\multicolumn{2}{|c|}{ Diagnosis }} & \multicolumn{8}{|c|}{ Males } & \multicolumn{7}{|c|}{ Females } \\
\hline & & \multirow{2}{*}{\multicolumn{2}{|c|}{ Total }} & \multirow{2}{*}{\multicolumn{2}{|c|}{$\begin{array}{l}\text { Living in } \\
\text { Damp } \\
\text { Houses }\end{array}$}} & \multicolumn{4}{|c|}{ Conditions at Work } & \multirow{2}{*}{\multicolumn{2}{|c|}{ Total }} & \multirow{2}{*}{\multicolumn{2}{|c|}{$\begin{array}{l}\text { Living in } \\
\text { Damp } \\
\text { Houses }\end{array}$}} & \multicolumn{3}{|c|}{ Conditions at Work } \\
\hline & & & & & & \multicolumn{2}{|c|}{ Cold } & \multicolumn{2}{|c|}{ Wet } & & & & & Cold & & \\
\hline & & No. & $\%$ & No. & $\%$ & No. 1 & $\%$ & No. & $\%$ & No. & $\%$ & No. & $\%$ & No. & No. & $\%$ \\
\hline $\begin{array}{l}\text { Total persons } \ldots \\
\text { Total rheumatic complaints }\end{array}$ & $\cdots$ & $\begin{array}{r}1,619 \\
508\end{array}$ & 31 & $\begin{array}{l}42 \\
13\end{array}$ & 31 & $\begin{array}{l}60 \\
22\end{array}$ & 51 & $\begin{array}{l}410 \\
208\end{array}$ & 51 & $\begin{array}{l}1,896 \\
653\end{array}$ & 34 & $\begin{array}{l}63 \\
20\end{array}$ & 32 & 11 & $\begin{array}{l}63 \\
40\end{array}$ & 63 \\
\hline $\begin{array}{l}\text { Osteo-arthritis . } \\
\text { Rheumatoid arthritis } \ldots \\
\text { Disk disorders . } \\
\text { Other rheumatic disorders } \\
\text { Undetermined rheumatism } \\
\text { Not stated } \quad \ldots \quad \ldots\end{array}$ & \begin{tabular}{l|}
$\cdots$ \\
$\cdots$ \\
$\cdots$ \\
$\cdots$ \\
$\cdots$
\end{tabular} & $\begin{array}{r}99 \\
28 \\
117 \\
42 \\
176 \\
46\end{array}$ & $\begin{array}{r}6 \\
2 \\
7 \\
3 \\
11\end{array}$ & $\begin{array}{l}2 \\
0 \\
6 \\
1 \\
4 \\
0\end{array}$ & $\begin{array}{r}5 \\
0 \\
14 \\
2 \\
10\end{array}$ & $\begin{array}{r}3 \\
0 \\
10 \\
1 \\
7 \\
1\end{array}$ & $\begin{array}{r}7 \\
0 \\
17 \\
2 \\
12\end{array}$ & $\begin{array}{r}39 \\
10 \\
57 \\
22 \\
71 \\
9\end{array}$ & $\begin{array}{r}10 \\
2 \\
14 \\
5 \\
17\end{array}$ & $\begin{array}{r}178 \\
81 \\
57 \\
55 \\
219 \\
63\end{array}$ & $\begin{array}{r}9 \\
4 \\
3 \\
3 \\
12\end{array}$ & $\begin{array}{r}10 \\
2 \\
2 \\
2 \\
4 \\
0\end{array}$ & $\begin{array}{r}16 \\
3 \\
3 \\
3 \\
6\end{array}$ & $\begin{array}{l}0 \\
0 \\
0 \\
0 \\
2 \\
0\end{array}$ & $\begin{array}{r}15 \\
4 \\
6 \\
1 \\
11 \\
3\end{array}$ & $\begin{array}{r}24 \\
6 \\
10 \\
2 \\
17\end{array}$ \\
\hline
\end{tabular}


TABLE VIII

RELATIONSHIP OF RHEUMATIC COMPLAINTS TO TYPE OF DWELLING, BY SEX

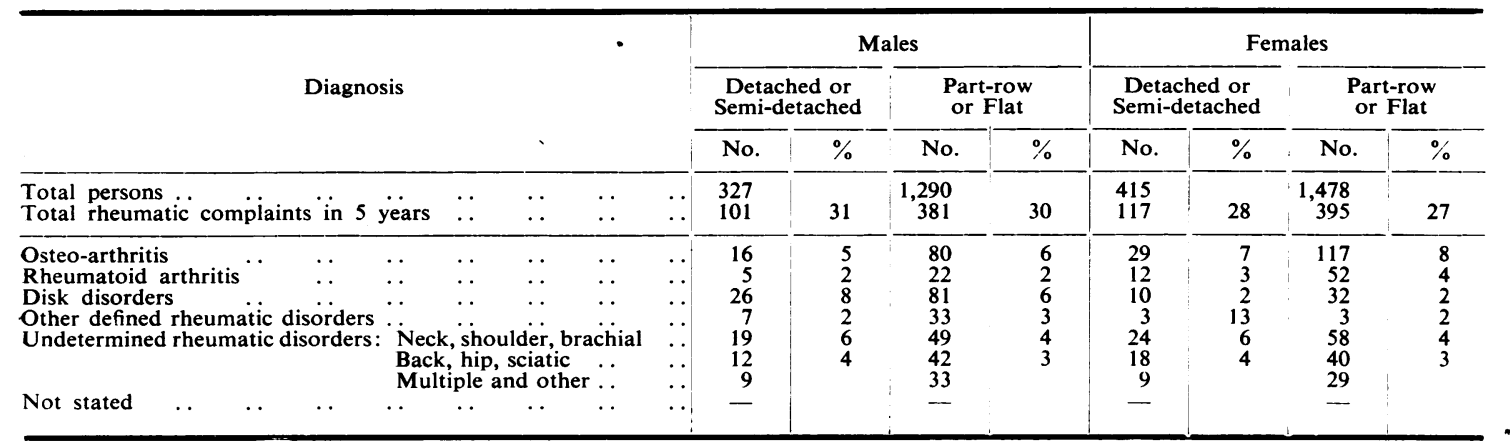

Housing.-There was no evidence that the type of dwelling had any influence on the incidence of rheumatic complaints (Table VIII). Such slight differences of incidence of undetermined rheumatic pain and osteo-arthritis as occurred could be accounted for by the different age distribution, there being more old people in the part-row houses or flats.

\section{Discussion}

This survey deals exclusively with the population of Leigh, and although the findings are probably representative of similar urban communities in the north-west of England, it is very doubtful if they can be applied to the country as a whole, since there is some evidence that the incidence of the rheumatic diseases varies from one part of England to another (Newman, 1924), and the medical services are by no means equally spread over the country as a whole. Comparison with previous estimates of incidence is not easy, since the Newman report (1924) dealing with rheumatic disease in England and Wales was based upon the records of general practitioners, thus excluding all those who did not consult their doctor. Furthermore, only the employed population covered by National Health Insurance was studied, and the small numbers in the older age groups, particularly amongst the females, suggest that this may have been a selected sample. A similar difficulty arises with the Scottish report on chronic rheumatic diseases (1945).

Both these reports deal with a single year, whereas our survey covered a 5-year period, and in addition we have used a somewhat different method of classification, but by taking our figures for loss of 1 week or more of working time (Table III), and by calculating the rates per 1,000 questioned, and dividing these by five to get an annual instead of a 5-year rate, a very rough comparison can be made (Table IX).

From this it will be seen that the total incapacity rates are not very different, but that in the present survey a greater proportion of incapacity was attributed to rheumatoid and osteo-arthritis. A similar rough comparison with the Newman report can be made by taking our figures for those individuals consulting their practitioners from Table IV and applying a similar calculation. Allowing for the fact that our population was all from the North-west of England where, according to the Newman report, there was considerably more rheumatism of all

TABle IX

COMPARISON WITH PREVIOUS SURVEYS

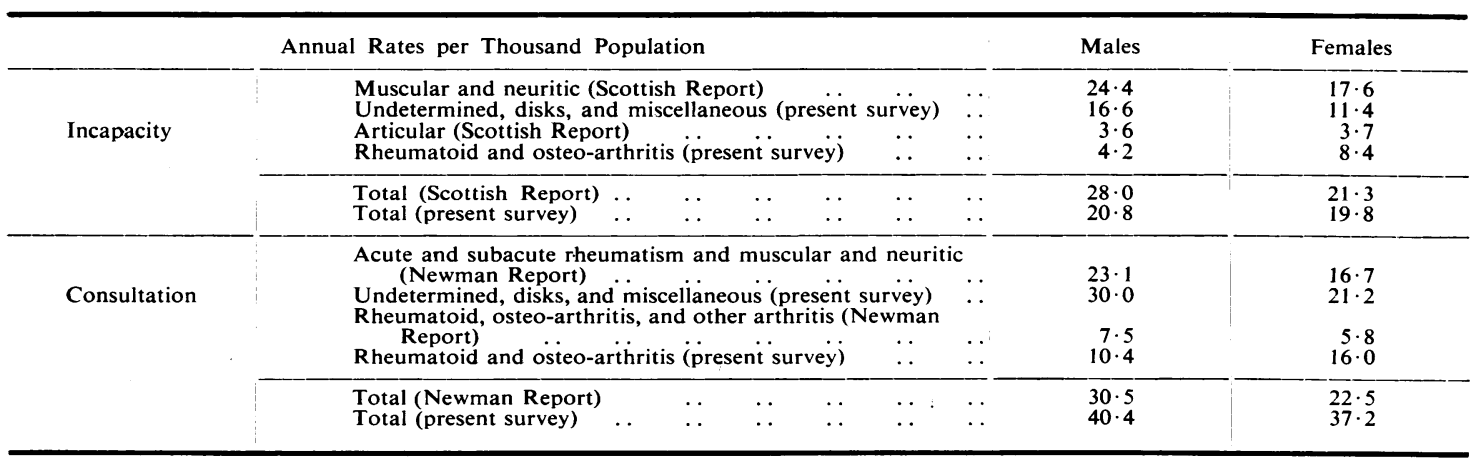


kinds, except gout, than in other areas, the figures are again not very different, except in the rheumatoid and osteo-arthritic group in females, where our findings give an incidence nearly three times greater. Our survey, however, deals with a sample of the total population, whereas the two previous reports dealt with employed persons only, the older females being a relatively small and possibly highly selected sample, and it is in the older women that we found such a high incidence of these diseases.

In the report of sickness in the population of England and Wales (Stocks, 1949) the total monthly complaint rate for those painful conditions of the limbs and back which are included in our survey, amounts to 23 per cent., which compares with our figure of 19 per cent. for the incidence of complaints present at the time of questioning, but the diagnostic breakdown given by Stocks is based upon the individual's self-diagnosis. This gives "lumbago and muscular rheumatism" an incidence of 16 per cent., and a further 3.9 per cent. is accounted for by undiagnosed limb and back pains, while all forms of arthritis are given a very low incidence. In particular a notoriously common condition such as osteoarthritis is given an incidence of less than 0.4 per 1,000 , an incidence identical with that given for tuberculosis of bones and joints. Thus self-diagnosis in this type of disease is clearly not reliable. However, owing to the very different methods employed, it is doubtful if any detailed comparison can usefully be made between our figures and those of the previous reports, since one cannot escape the conclusion that different diagnostic criteria have been used.

Two of our findings require special comment:

(a) the high incidence of osteo-arthritis in females;

(b) the importance of disk disorders as a cause of pain and disability.

Apart from its high incidence, osteo-arthritis amongst the females differed in other ways from osteo-arthritis in males. Thus osteo-arthritis in the females was more often associated with pain at multiple sites-35 per cent. as against 20 per cent. in males. In females there was also a less significant association between osteo-arthritis and injury than in the males; and in females osteo-arthritis was distributed evenly throughout the occupational groups, whereas in males there was a higher incidence in laborious occupations like mining than in the sheltered group of tradesmen. It has recently been suggested (Kellgren and Moore, 1952) that there is a generalized constitutional form of osteo-arthritis which is distinct from what is generally considered as degenerative joint disease, and that this generalized condition is found predominantly amongst females. Unfortunately, this distinction was not made at the time of the survey, but we suggest that the differences 3 between osteo-arthritis in males and females noted므. here may be due to the inclusion of a large propor- - ? tion of this more generalized constitutional disease $\overrightarrow{\bar{F}}$ in the osteo-arthritic group of females.

Our group of disk disorders undoubtedly contains $\frac{}{0}$ many of the painful conditions previously called $\overline{\bar{c}}$. muscular or neuritic, and for which the term $\vec{\Phi}$ "fibrositis" was often employed. In disk degenera- 응 tion, as in degenerative conditions of the limb joints, ${ }^{\infty}$ disabling painful episodes occur which may repre- $\vec{O}$ sent simple sprains and strains of the muscles and $\vec{\omega}$ ligaments controlling mechanically inefficient joints, $\vec{\omega}$ so that symptoms may be in that sense muscular in origin. And amongst the painful conditions of un-? determined nature there may also have been a $\vec{N}$ number of similar muscular strains, as well as $-\vec{G}$ examples of epidemic myalgias of the coxsackie type, $\circ$ together with a host of ill-defined partly psychogenic $\stackrel{-}{-}$ disorders; but we could not define any condition that $\vec{z}$ could well be labelled "primary fibrositis".

The aetiological factors studied appeared to have $\frac{\bar{\partial}}{\widetilde{S}}$ no influence upon the incidence of rheumatoid $\vec{C}$ arthritis, thus confirming the previous finding of the of Empire Rheumatism Council (1950). On the other hand, laborious occupations and trauma were associated with a high incidence of osteo-arthritis and disk degeneration, particularly in males, and pain due to these conditions was associated with claims to $\frac{\mathscr{Q}}{\triangle}$ unusual exposure to wet and cold, but the signifi- $\varrho$ cance of this is not clear.

\section{Summary}

(1) A survey has been made of rheumatic complaints in a sample of the general population of a Lancashire town-3,515 individuals over the age $\frac{0}{2}$ of 15 years were questioned by a social worker. Of these, 1,407 stated that they had had some 3 . rheumatic complaint, and 1,309 were examined.

(2) The incidence of "complaints since birth" was 40 per cent.; that of "complaints in the 5 years 을 prior to the survey" was 33 per cent., and that of "complaints present at the time of survey" was 19 per cent. The small difference between the first two rates is probably due to the effects of memory. $O$ The difference between the second two rates is $N$ largely due to the episodic nature of the symptoms in many conditions such as rheumatic fever, gout, disk disorders, and trivial undetermined complaints.

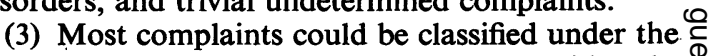
main headings of osteo-arthritis, rheumatoid arth- $\stackrel{?}{+}$ ritis, disk disorders, and complaints of undeter- $\square$ mined nature, and the age incidence, degree of disability, etc., were analysed in detail.

(4) Nearly half those with complaints had failed to $\stackrel{?}{\mathbb{D}}$ consult a general practitioner. One-eighth were $\frac{\Omega}{\sigma}$ 
referred to hospital as out-patients, roughly equivalent to the number losing more than 3 months of working time, and one-quarter were admitted.

(5) Some association was noted between a history of injury and complaints due to osteo-arthritis, particularly in men. Laborious occupations and a claim of unusual exposure to cold and wet also showed some association with complaints due to osteo-arthritis and disk disorders.

(6) When compared with previous studies, this survey shows a similar total incidence of complaints, but a different allocation to diagnostic groups. This may be partly due to the different populations studied, but also probably to a change of diagnostic criteria, more complaints being attributed to osteoarthritis, rheumatoid arthritis, and disk disorders in the present study, and fewer to the non-articular forms of rheumatism.

We are most grateful to Professor R. E. Lane for advice in the planning and conduct of this survey, and to Miss Nancy Goodman for much work on the statistical aspects. We also wish to thank Dr. O. Janus and the other physicians who helped in the field work.

\section{REFERENCES}

Friberg, S., and Hirsch, C. (1949). Acta orthop. scand., 19, 222.

Kellgren, J. H., and Lawrence, J. S. (1952). Brit. J. industr. Med., 9. 197.

McGowan, A. J., and Hughes, E. S. R. (1948). Clin. Sci., 7, 13.

-, and Moore, R. (1952). Brit. med. J., 1, 181 .

Lawrence, J. S., and Aitken-Swan, J. (1952). Brit. J. industr. Med., 9,1 .

Lewis-Faning, E., ed. (1950). “Empire Rheum atism Council Report on an Enquiry into the Aetiological Factors Associated with Rheumatoid Arthritis." Annals of the Rheumatic Diseases, Suppl., vol. 9

Ministry of Health (1924). "The Incidence of Rheumatic Diseases", ed. G. Newman. Reports on Public Health and Medical Subjects, No. 23. H.M.S.O., London.

Schmorl, G., and Junghanns, H. (1951). "Die Gesunde und Kranke Wirbelsäule in Röntgenbild und Klinik", 2nd ed. Thieme, Stuttgart.

Scotland, Department of Health (1945). "Chronic Rheumatic Diseases". Report of the Medical Advisory Committee (Scotland). H.M.S.O., Edinburgh.

Stocks, P. (1949). "Sickness in the Population of England and Wales 1944-1947", General Register Office, Studies on Medical and Population Subjects, No. 2. H.M.S.O., London.

Symptômes rhumatismaux dans une population urbaine RÉSUMÉ

(1) On a préparé un relevé des symptômes rhumatismauu dans une section de la population générale d'une ville de Lancashire (Angleterre): 3,515 personnes âgées de plus de 15 ans furent interrogées. De ce nombre, 1,407 ont déclaré avoir présenté des manifestations rhumatismales et 1,309 d'entre eux ont été examinées.

(2) La fréquence des "symptômes depuis la naissance", s'élevait à $40 \%$, celle des "symptômes au cours des 5 années antérieures au relevé" à $33 \%$, et celle des "symptômes existant au moment du relevé" à $19 \%$. La petite différence entre les deux premiers pourcentages est due probablement à des défauts de mémoire. La différence entre les deux derniers pourcentages est due en grande partie à la nature épisodique des symptômes dans de nombreuses affections, telles que rhumatisme articulaire aigu, goutte, troubles discaux, et et de symptômes banaux de nature indéterminée.

(3) On pourrait placer la plupart des symptômes sous les titres généraux d'ostéoarthrite, d'arthrite rhumatismale, de troubles discaux, et de manifestations de nature indéterminée. La fréquence selon l'âge, le degré de l'infirmité etc. furent analysés de point en point.

(4) Presque la moitié n'a pas consulté leur médecin. Un sur huit fut dirigé à la clinique hôpitalière. Le même nombre à peu près, perdit plus de 3 mois de travail, et un quart fut admis à l'hôpital.

(5) On a noté qu'il y avait un rapport entre les antécédents traumatiques et les manifestations ostéoarthritiques, surtout parmi les hommes. Les occupations laborieuses et l'affirmation d'avoir été trop exposé au froid et à l'humidité montraient également une certaine association avec des symptômes d'ordre ostéoarthritique et des troubles discaux.

(6) Ce relevé montre que la fréquence des symptômes rhumatismaux était similaire à celle trouvée au cours des études précédentes, mais que leur distribution entre les groupes diagnostiques était différente. Cela peut s'expliquer en partie par la différence entre les populations étudiées et aussi, peut-être, par des critères diagnostiques modifiés, des symptômes étant attribués dans cette étude plus souvent à l'ostéoarthrite, à l'arthrite rhumatismale, et aux troubles discaux, et moins souvent aux formes non-articulaires de rhumatisme.

\section{Manifestaciones reumáticas en una población urbana Sumario}

(1) Un informe fué preparado sobre manifestaciones reumáticas en una sección de la población general de una ciudad de Lancashire (Inglaterra). 3,517 personas de más de 15 años de edad fueron interrogadas. De este número, 1,407 declararon haber presentado manifestaciones reumáticas y 1,309 fueron examinadas.

(2) La incidencia de "síntomas desde nacer" fué de $40 \%$, la de "síntomas en el curso de los 5 años anteriores al informe" de $33 \%$, y la de "síntomas presentes al tiempo del informe" de $19 \%$. La pequeña diferencia entre los dos primeros porcentajes se debe probablemente a defectos de memoria. La diferencia entre los dos últimos porcentajes se debe en gran parte a la naturaleza episódica de los síntomas en varias afecciones, como el reumatismo poliarticular agudo, la gota, los disturbios del disco intervertebral, y un gran número de síntomas banales de naturaleza indeterminada.

(3) Se puede repartir la mayoría de las manifestaciones entre los títulos generales de osteoartritis, artritis reumatoide, disturbios discales, y manifestaciones de naturaleza indeterminada. La incidencia según la edad, el grado de la incapacidad etc. fueron analizados detalladamente.

(4) Casi la mitad no consultaron nunca a un médico. Una octava parte fué enviada a la clínica hospitalaria. El mismo número perdió más de 3 meses de trabajo, y la cuarta parte fué internada en el hospital.

(5) Se notó la existencia de una relación entre antecedentes traumáticos $\mathrm{y}$ manifestaciones osteoartríticas, particularmente respecto a los varones. Ocupaciones laboriosas y exposición exagerada al frío y a la humedad mostraron también cierta asociación con síntomas debidos a la osteoartritis y a disturbios discales.

(6) Al comparar este informe con los estudios anteriores, se nota una similaridad de la incidencia total de las manifestaciones pero una diferencia en la distribución entre grupos diagnósticos. Eso podría explicarse en parte por una diferencia entre las poblaciones estudiadas y también, quizás, por criterios diagnósticos cambiados, atribuyéndose los síntomas en este estudio màs a osteoartritis, artritis reumatoide, y a disturbios discales, y menos a formas extra-articulares del reumatismo. 